\title{
Differences in PAR-2 activating potential by king crab (Paralithodes camtschaticus), salmon (Salmo salar), and bovine (Bos taurus) trypsin
}

\author{
Anett K Larsen ${ }^{1,2}$, Kurt Kristiansen², Ingebrigt Sylte ${ }^{2}$, Ole-Morten Seternes ${ }^{3}$ and Berit E Bang ${ }^{1,2^{*}}$
}

\begin{abstract}
Background: Salmon trypsin is shown to increase secretion of the pro-inflammatory cytokine interleukin (IL)-8 from human airway epithelial cells through activation of PAR-2. Secretion of IL-8 induced by king crab trypsin is observed in a different concentration range compared to salmon trypsin, and seems to be only partially related to PAR-2 activation. This report aim to identify differences in the molecular structure of king crab trypsin (Paralithodes camtschaticus) compared to salmon (Salmo salar) and bovine trypsin (Bos taurus) that might influence the ability to activate protease-activated receptor-2 (PAR-2).
\end{abstract}

Results: During purification king crab trypsin displayed stronger binding capacity to the anionic column used in fast protein liquid chromatography compared to fish trypsins, and was identified as a slightly bigger molecule. Measurements of enzymatic activity yielded no obvious differences between the trypsins tested. Molecular modelling showed that king crab trypsin has a large area with strong negative electrostatic potential compared to the smaller negative areas in bovine and salmon trypsins. Bovine and salmon trypsins also displayed areas with strong positive electrostatic potential, a feature lacking in the king crab trypsin. Furthermore we have identified 3 divergent positions ( $\mathrm{Asp}^{196}, \mathrm{Arg}^{244}$, and $\mathrm{Tyr}^{247}$ ) located near the substrate binding pocket of king crab trypsin that might affect the binding and cleavage of PAR-2.

Conclusion: These preliminary results indicate that electrostatic interactions could be of importance in binding, cleavage and subsequent activation of PAR-2.

Keywords: King crab trypsin, Molecular modelling, Protease-activated receptor-2, Electrostatic interaction

\section{Background}

Trypsin is a known activator of protease-activated receptor (PAR)-2 [1,2]. Receptor activation by proteases is achieved by proteolytic cleavage of the $\mathrm{N}$-terminal sequence. This cleavage unmasks a new amino terminus that serves as a tethered ligand that binds to conserved regions in the body of the receptor, resulting in the initiation of signal transduction [3]. Exogenously applied synthetic peptides based on the sequence of the tethered ligand are also capable of activating PARs by directly binding to the body of the receptor. To date, four PARs

\footnotetext{
*Correspondence: berit.bang@unn.no

'Department of Occupational- and Environmental Medicine, University Hospital North Norway, Tromsø, Norway

${ }^{2}$ Medical Pharmacology and Toxicology, Department of Medical Biology,

Faculty of Health Sciences, University of Troms $\varnothing$, Troms $\varnothing$, Norway

Full list of author information is available at the end of the article
}

have been cloned and characterized; PAR-1, PAR-2, PAR-3, and PAR-4. PARs have emerged as important receptors in airway inflammation and allergy, and PARs are expressed in all cell types that participate in the inflammatory response of the lung; epithelial cells, mast cells, macrophages, infiltrated neutrophils and eosinophils, fibroblasts, smooth muscle cells, endothelial cells, lymphocytes, and neurons $[4,5]$.

Our previous work has confirmed that purified salmon trypsin increase secretion of the pro-inflammatory cytokine interleukin (IL)-8 from human airway epithelial cells through activation of PAR-2 [6]. Secretion of cytokines from the airway epithelium contributes to an inflammation response and can be induced by both endogenous and exogenous proteases [3]. Based on the knowledge that occupational airway symptoms are frequently presented by workers handling different species 
of fish and crustaceans [7-15], we have tested several types of seafood trypsins in our cell based assays. This in order to investigate possible initiation of signal transduction connected to inflammation processes in human airway epithelial cells $[6,16]$. During purification of numerous fish trypsins (Atlantic salmon [Salmo salar], sardine [Sardinops melanostictus], anchovy [Engraulis japonicus], jacopever [Sebastes schlegelii], yellow tail [Seriola quinqueradiata], spotted mackerel [Scomber australasicus] ) and trypsin from the king crab (Paralithodes camtschaticus) by fast protein liquid chromatography (FPLC), we observed that king crab trypsin bound stronger to the anionic column compared to the fish trypsins we purified.

Molecular size, conformation and electrostatic potential will influence on a molecule's ability to bind and interact with signalling partners. To bind tightly, the ligand must possess a shape and a charge distribution that are complementary to the target receptor $[17,18]$. In the molecular complex formed, attractive van der Waals and electrostatic (charge-charge) interactions are made across the binding interface. While the van der Waals interactions are relatively non-specific and small in magnitude, the electrostatic (charge-charge) interactions are highly specific and act over a significantly longer range. A small chemical change as conversion of one amino acid from Lto $\mathrm{D}$ - form or substitution of amino acids can inactivate the molecule, as the receptor may fail to bind the altered form or bind it less efficiently. The nature of the interaction between two signalling partners will influence upon downstream signalling pathways following molecular interaction leading to activation and transmission of the molecular signal (full or partial agonists) or inactivation without signal transduction (antagonists) [19].

We decided to explore the observed divergence between king crab and fish trypsins further. Purified salmon, sardine, bovine and king crab trypsins were evaluated by their ability to hydrolyze a chromogenic substrate (DL-BAPNA) and molecular modelling was executed of salmon, bovine and king crab trypsins for comparison of molecular structure and possibly identification of important amino acids in the trypsin - PAR-2 interaction.

\section{Methods}

\section{Materials}

Na-Benzoyl- ${ }_{D, L}$-arginine 4-nitroanilide hydrochloride (DLBAPNA) and trypsin from bovine pancreas (T7309) were purchased from Sigma-Aldrich, MO, USA. Purified salmon trypsin was kindly provided by Dr. Nils Peder Willassen and Dr. Ronny Helland (University of Tromsø). King crab trypsin was manufactured by Dr. Galina N. Rudenskaya (Moscow State University), and the sardine trypsin was supplemented by Dr. Hideki Kishimura (Hokkaido University).

\section{Protein determination}

The protein concentration was determined with a NanoDrop ND-1000 spectrophotometer (Thermo Scientific) using the Protein A280 determination module.

\section{Fast protein liquid chromatography (FPLC)}

All purification steps were carried out at $0-4^{\circ} \mathrm{C}$. The freeze dried trypsins prepared according to Rudenskaya et al. [20], Kislitsyn et al. [21], and Kishimura et al. [22] were re-suspended in $25 \mathrm{mM}$ TrisHCl, $\mathrm{pH} 7.5$ and applied to a $1.5 \mathrm{ml}$ benzamidine-sepharose $6 \mathrm{~B}$ column equilibrated with $25 \mathrm{mM}$ TrisHCl, $10 \mathrm{mM} \mathrm{CaCl}, 500 \mathrm{mM} \mathrm{NaCl}, \mathrm{pH}$ 7.5. Bound trypsin was eluted using $120 \mathrm{mM}$ benzamidine and collected in $1.5 \mathrm{ml}$ fractions. All fractions with enzymatic activity measured by the serine protease assay (DL-BAPNA) were pooled and dialyzed against $25 \mathrm{mM}$ TrisHCl, $10 \mathrm{mM} \mathrm{CaCl}_{2}, \mathrm{pH} 7.5$ at $4^{\circ} \mathrm{C}$ over night using 10K Slide-A-Lyzer dialysis cassettes from Pierce, IL, USA. The following day the benzamidine purified trypsins were applied to a $1 \mathrm{ml}$ Resource $\mathrm{Q}$ ion exchange column equilibrated with $25 \mathrm{mM}$ Tris $\mathrm{HCl}, 10 \mathrm{mM} \mathrm{CaCl}_{2}, \mathrm{pH} 7.5$ and the enzymes were eluted with $1 \mathrm{M} \mathrm{NaCl}$ using a $7.5 \%$ gradient for 10 fractions (total of $5 \mathrm{ml}$ ) followed by a linear gradient rising to $100 \%$ in 20 fractions (total of $10 \mathrm{ml}$ ). Fractions corresponding to the observed peaks were tested for enzymatic activity and pooled before dialysis as described previously.

\section{SDS-PAGE}

After purification the trypsins were run on a sodium dodecyl sulfate polyacrylamide gel electrophoresis (SDSPAGE) (4-12\% NUPAGE; Invitrogen) and stained with SilverQuest ${ }^{\mathrm{TM}}$ Silver Staining Kit (Invitrogen) for verification of their purity.

\section{Protease activity determination}

The enzymatic activity of the purified trypsins was determined by a serine protease assay where the hydrolyzation of a chromogenic substrate (DL-BAPNA) was measured spectrophotochemically by the increase in absorbance at $405 \mathrm{~nm}$ at room temperature or $37^{\circ} \mathrm{C}$ for the length of $10 \mathrm{~min}$. The substrate was diluted in substrate buffer (25 mM TrisHCl, $10 \mathrm{mM} \mathrm{CaCl}_{2}$, 2\% (v/v) DMSO, pH 8.1) and used at a final concentration of $0.5 \mathrm{mM}$. The activity was measured in a total volume of $250 \mu \mathrm{l}(10 \mu \mathrm{l}$ of enzyme and $240 \mu \mathrm{l}$ of diluted substrate) in clear, 96 well trays with flat bottom (BD Falcon, NJ, USA). The results were expressed as units $(\mathrm{U}) / \mathrm{ml}$ [23], and one unit of activity was defined as $1 \mu \mathrm{mol}$ substrate hydrolyzed per minute using an extinction coefficient of $8800 \mathrm{M}^{-1} \mathrm{~cm}^{-1}$ [24]. The calculations were made using the following formula: Unit: $\mathrm{dA} / \mathrm{dt} \times 1 /\left(\varepsilon \times\right.$ optical path length $\left.\times 10^{6}\right) \times \mathrm{V}_{\text {final }}$, where $\mathrm{dA} / \mathrm{dt}=$ rate of absorbance change and $\varepsilon=$ extinction coefficient. 


\section{Molecular modelling}

A homology model of king crab trypsin (Paralithodes camtschaticus; TREMBL accession code: Q8WR10 PARCM) was built by using ICM3.5 [25] and the crystal structure of Atlantic salmon trypsin (pdb code: 1hj8) as a structural template. The homology model of king crab trypsin, the structures of Atlantic salmon trypsin (pdb code: 1hj8) and bovine trypsin (pdb code: 1s0r) were superimposed on the thrombin-PAR-4 structure (pdb code: 2pv9; [26]). The backbone of the catalytic site residues in the trypsins were superimposed with the corresponding residues of the PAR-4-thrombin complex. A model of the N-terminal fragment of human PAR-2 $\left(\mathrm{Gly}^{28}-\mathrm{Val}^{53}\right)$ was build and superimposed on top of the corresponding PAR-4 segment in the crystal structure of the thrombin-PAR-4 complex. Electrostatic potentials were calculated on the molecular surfaces of the model and structures of the trypsins.

\section{Results} SDS-PAGE

King crab trypsin is reported to be in the size range of 23 - 29 kDa (Kislitsyn et al., [21]; Rudenskaya et al., [20]). Our results from SDS-PAGE reveal a protein in the 28 - $29 \mathrm{kDa}$ range (Figure 1) compared to sardine trypsin at $24 \mathrm{kDa}$ [22] (Figure 1), and salmon trypsin at $23,7-25 \mathrm{kDa}[23,27]$.

\section{Effect of temperature on enzymatic activity}

The effect of temperature on the enzymatic activity of four different trypsins (bovine, salmon, sardine, and king crab) was examined using the substrate DL-BAPNA at room temperature and $37^{\circ} \mathrm{C}$. As depicted in Figure 2, the total enzymatic activity of all trypsins decreased with lowered protein concentration. Comparing the enzyme activities at room temperature showed that salmon and

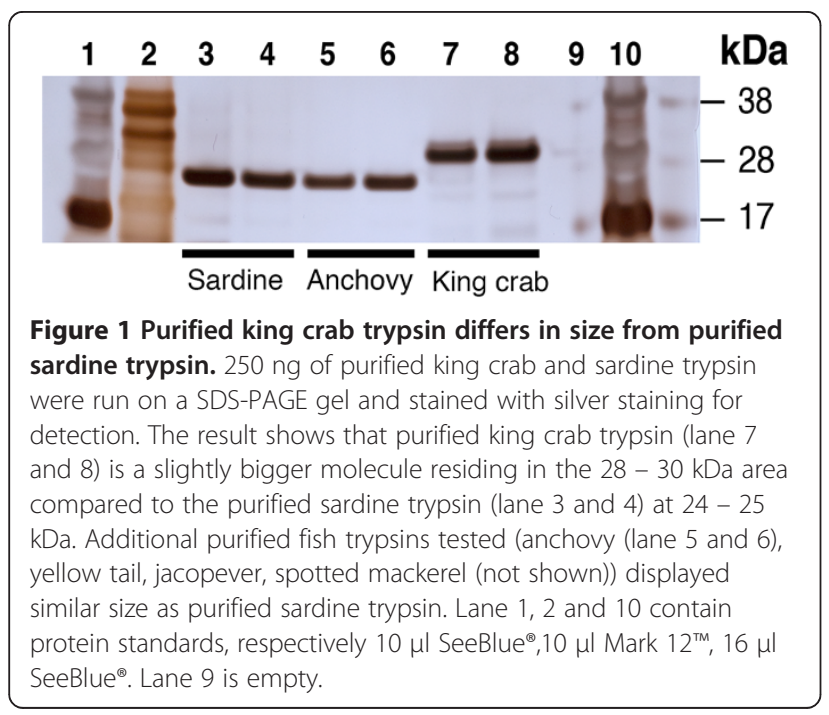

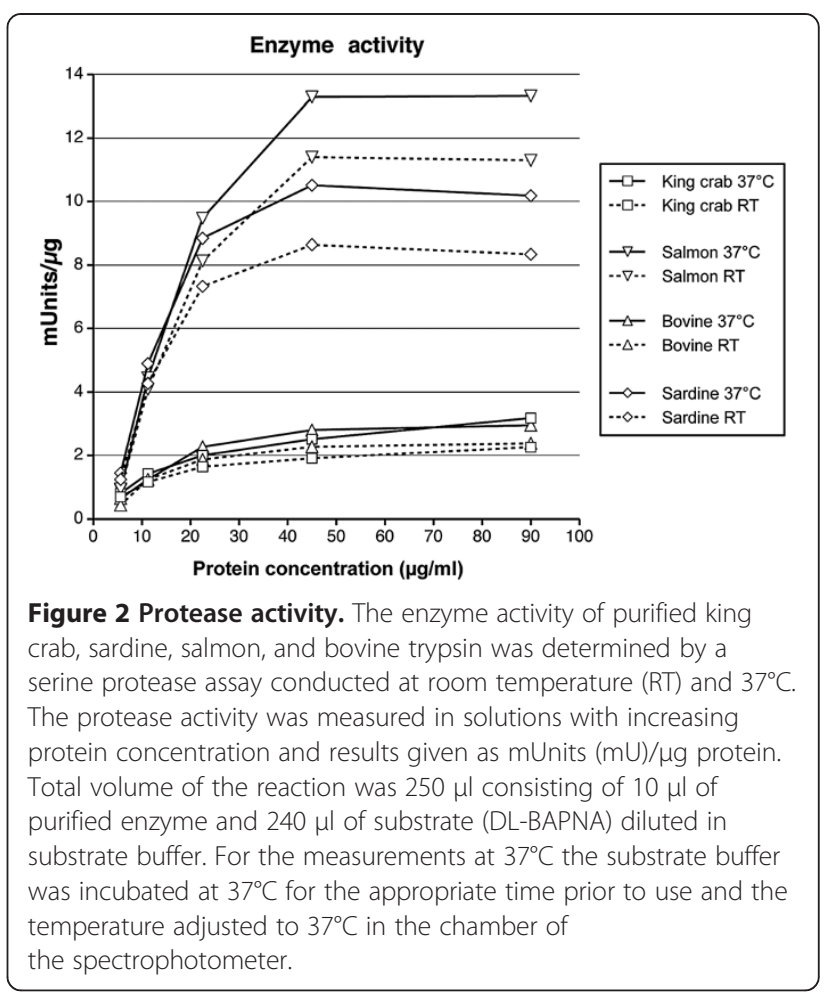

sardine trypsin exhibited higher enzyme activity (11.3 and $8.34 \mathrm{mU} / \mu \mathrm{g}$, respectively), as compared to king crab and bovine trypsin $(2.26$ and $2.38 \mathrm{mU} / \mu \mathrm{g})$, using enzyme solutions with a protein concentration of $90 \mu \mathrm{g} / \mathrm{ml}$. All trypsins showed an increased enzymatic activity when increasing the temperature to $37^{\circ} \mathrm{C}$ (Figure 2). The purified king crab trypsin showed the most pronounced increment with a $29 \%$ rise in enzymatic activity at the highest protein concentration, compared to $19.3 \%$ in the bovine trypsin, $18.1 \%$ in the purified sardine trypsin, and $15.2 \%$ in the purified salmon trypsin. The mean rise in enzymatic activity was $20.6 \%$ for the purified king crab trypsin, $17.7 \%$ for the bovine trypsin, $15.9 \%$ for the purified sardine trypsin, and $9.6 \%$ for the purified salmon trypsin. As for the total enzymatic activity, the degree of increment was also reduced with lowered protein concentration for all trypsins.

\section{Molecular modelling shows differences in the protein structure of the king crab trypsin compared to salmon and bovine trypsin}

The surface of king crab trypsin has a large area with strong negative electrostatic potential (Figure 3a). The surface of bovine trypsin has smaller areas with strong negative potential, in particular around $\mathrm{Asp}^{171}$ at the catalytic site, and also areas with strong positive electrostatic potential (Figure 3c).

Comparison of the homology model of king crab trypsin with the structures of Atlantic salmon and bovine 



Figure 3 Molecular modelling of king crab, salmon, and bovine trypsin. a - c: Electrostatic surfaces of (A) king crab trypsin (homology model), (B) bovine trypsin (pdb code: 1s0r), and (C) Atlantic salmon trypsin (pdb code: 1hj8). The most electropositive potential is shown in blue, whereas the most electronegative potential is shown in red. The PAR-2 agonist peptide is displayed in green ribbon. $\mathbf{d}$ : The $\mathrm{N}$-terminal fragment of PAR-4 and PAR-2, Arg at the cleavage site (shaded), *: a conserved positive charged residue in tethered peptides. e and $\mathbf{f}$ : The location of 3 binding site residues in the king crab trypsin model that corresponds to different residues in the bovine and Atlantic salmon trypsin (shaded boxes in the structural alignment). Asp ${ }^{196}$ in king crab trypsin corresponds to Met ${ }^{175}$ in Atlantic salmon and $\mathrm{Gln}^{155}$ in bovine trypsin; Arg ${ }^{244}$ in the king crab trypsin corresponds to Glu ${ }^{221}$ in Atlantic salmon and $\mathrm{Gln}^{199}$ in bovine trypsin; and Tyr ${ }^{247}$ in king crab trypsin corresponds to Asn ${ }^{224}$ in Atlantic salmon trypsin and to Lys ${ }^{202}$ in bovine trypsin.

trypsin suggested that at least 3 divergent positions are located near the substrate binding pocket (Figure 3d): Asp ${ }^{196}$ in king crab trypsin corresponds to $\mathrm{Met}^{175}$ in the Atlantic salmon trypsin structure and to $G \ln ^{155}$ in the bovine trypsin structure; $\operatorname{Arg}^{244}$ in king crab trypsin corresponds to $\mathrm{Glu}^{221}$ in Atlantic salmon trypsin and to Gln ${ }^{199}$ in bovine trypsin; while $\mathrm{Tyr}^{247}$ in king crab trypsin corresponds to $\mathrm{Asn}^{224}$ in salmon trypsin and to Lys $^{202}$ in bovine trypsin.

\section{Discussion}

A recent study by Ramachandran and co-workers [28] reports the ability of PAR-2 to exhibit functional selectivity where the proteolytically revealed tethered ligand 
(TL) sequence(s) and the mode of its presentation to the receptor (tethered vs. soluble) can confer biased signalling. Thus, PAR-2 can signal to multiple pathways that are differentially triggered by distinct protease-revealed tethered ligands. Differential signalling depending on the activating ligand (termed "agonist-biased signalling" or "functional selectivity") are also reported for other G protein-coupled receptors [29-32]. The exact factors that lead to activation of different signal pathways during binding of agonist to and cleavage of PAR-2 are unknown. Molecular modelling of the human PAR-1 has revealed various electrostatic, steric, and hydrophobic interactions between receptor and the antagonist used in docking studies [33]. Some residues identified as main points for electrostatic interactions have previously been reported as important in site directed mutagenesis studies for PAR-1 function and activity (Asp ${ }^{256}$ and $\mathrm{Glu}^{347}$ ) [34]. It is tempting to speculate that functional selectivity is a result of different capacity in the agonists to bind at these various interaction points.

Furthermore, the positive $\mathrm{Arg}^{5}$ in the agonist peptide is from receptor chimera studies in PAR-1 suggested to interact with the negative $\mathrm{Glu}^{260}$ in the second extracellular loop of PAR-1 during receptor activation [35,36]. Since these amino acids are conserved in PAR-2 an $\mathrm{Arg}^{5}-\mathrm{Glu}^{232}$ interaction might operate in recognition of the PAR-2 agonist peptide SLIGRL by the receptor. Changing this residue in the PAR-2 agonist peptide (the positive $\mathrm{Arg}^{5}$ in SLIGRL to a neutral alanine or a negative glutamatic acid creating SLIGAL or SLIGEL) markedly reduces the peptides' potency to cause intracellular $\mathrm{Ca}^{2+}$ signalling [37]. The Al-Ani study [37] indicate that changes in the net charge of interacting amino acids influence on activating capacity; a result that may be due to interference with electrostatic interactions.

Differences in IL-8 secreting potential and NF- $\mathrm{kB}$ activation have been identified for salmon and king crab trypsin. Both effects are coupled to PAR-2 activation, but only partly for the king crab trypsin [6,16]. Molecular modelling shows that the surface of king crab trypsin has a large area with strong negative electrostatic potential compared to the smaller areas of bovine and salmon trypsins. In addition, these latter trypsins also display areas with strong positive electrostatic potential, a feature lacking in king crab trypsin. Because of the lack of a full amino acid sequence of the sardine trypsin molecule we were not able to do any modelling of and comparison with sardine trypsin.

The modelling of bovine, salmon, and king crab trypsin suggests that at least 3 divergent positions are located near the substrate binding pocket and might affect the binding of substrate to PAR-2:

1) The negative Asp $^{196}$ in king crab trypsin corresponds to the neutral Met ${ }^{175}$ in salmon trypsin and the neutral $\operatorname{Gln}^{155}$ in bovine trypsin.
2) The positive $\mathrm{Arg}^{244}$ in the king crab trypsin corresponds to the negative $\mathrm{Glu}^{221}$ in salmon trypsin and the neutral $\operatorname{Gln}^{199}$ in bovine trypsin.

3) The neutral $\mathrm{Tyr}^{247}$ in king crab trypsin corresponds to the neutral $\mathrm{Asn}^{224}$ in salmon trypsin and to the positive Lys $^{202}$ in bovine trypsin.

It is possible that the positive $\mathrm{Arg}^{36}$ and/or positive Lys $^{34}$ of PAR-2 may interact differently with the binding pocket in the three trypsins. Because of differences in the electrostatic potential it is possible that PAR-2 might bind weaker to king crab trypsin than to other trypsins due to repulsive interactions between the positive $\mathrm{Lys}^{34} / \mathrm{Arg}^{36}$ in PAR-2 and the positively charged $\mathrm{Arg}^{244}$ in king crab trypsin. This residue corresponds to a negative amino acid $\left(\mathrm{Glu}^{221}\right)$ in salmon trypsin and a neutral amino acid $\left(G n^{199}\right)$ in bovine trypsin. Zhang and co-workers [38] have recently documented that long-range electrostatic interactions presumably play an important role in aligning the PAR-2 N-terminal polypeptide with the activating protease (factor VIIa (FVIIa)) domain during binding and subsequent activation of PAR-2. By molecular simulations they show that positive amino acids in the proximity of the cleavage site of PAR-2 ( $\mathrm{Arg}^{31}, \mathrm{Lys}^{34}$, and Arg $\left.{ }^{36}\right)$ are located close to negatively charged residues on the binding pocket surface of FVIIa, whereas the negatively charged $\mathrm{Asp}^{43}$ and $\mathrm{Glu}^{56}$ are close to positively charged FVIIa residues. Although cell-based control studies were not conclusive (antibodies blocking possible PAR-2 interacting residues in the FVIIa molecule resulted in inhibited tissue factor (TF)-FVIIa signalling through PAR-2, while charge reversal mutations in FVIIa (positive $\mathrm{Arg}^{62}$ to negative $\mathrm{Glu}^{62}$, and positive $\mathrm{Arg}^{84}$ to negative $\mathrm{Glu}^{84}$ ) did not significantly inhibit PAR-2 activation), we can not eliminate the possibility that electrostatic interactions in specific regions guide substrate orientation under physiological conditions. However, the specific FVIIa Arg ${ }^{62}$ - PAR-2 Glu ${ }^{56}$ interaction seems not to be essential for PAR-2 activation by TF-FVIIa.

The measurement of enzymatic activity at different concentrations both at room temperature and $37^{\circ} \mathrm{C}$ using DL-BAPNA as substrate yielded two separate but similar patterns among the four types of trypsins tested, with bovine and king crab trypsin in the lower area and the fish trypsins in the higher area. During the purification process the bovine trypsin behaved like the fish trypsins with regards to the binding capacity, giving rise to an inconsistency as it had similar enzymatic activity as the king crab trypsin. On the other hand, binding of trypsins to the N-terminal end of PAR-2 for cleavage and subsequent receptor activation might behave different from the binding and cleavage of the substrate in the serine protease assay, giving rise to differences in agonist potential in cell based assays. 
These preliminary results indicate that electrostatic interactions can be of importance in binding, cleavage and subsequent activation of PAR-2, and that difference in electrostatic charge in residues at key interacting positions may result in altered potency of the agonist in question. However, more extensive molecular modelling of the entire PAR-2 together with docking studies of different agonists and functional binding assays (Isothermal Titration Calorimetry, Fluorescence Resonance Energy Transfer) to independently quantify the binding capacity of all the trypsins to PAR-2 peptide would be highly interesting. Mutations of key amino acids or generation of chimeric trypsins to investigate the structure and activity relationship, along with cell based assays, are necessary to identify essential residues that might influence upon functional selectivity.

\section{Conclusion}

The results indicate that electrostatic interactions could be of importance in binding, cleavage and subsequent activation of PAR-2 and differences in electrostatic charge in residues at key interacting positions may result in altered potency of the agonists in questions.

\section{Availability of supporting data}

The models constructed in this study are available from the authors upon request.

\section{Competing interests}

The authors declared that they have no competing interest.

\begin{abstract}
Authors' contributions
AKL carried out the fast protein liquid chromatography, the SDS-PAGE, the measurements of enzymatic activity and drafted the manuscript. KK carried out the molecular modelling and drafted the appurtenant sections. IS participated in the study design and provided critical evaluation of the manuscript. OMS and BB conceived of the study, participated in its design and coordination and helped to draft the manuscript. All authors read and approved the final manuscript.
\end{abstract}

\section{Acknowledgments}

We thank the personnel at NORSTRUCT, University of Tromsø for excellent technical assistance during purification of the trypsins. This work was supported by Northern Norway Regional Health Authority (Helse Nord RHF), 8038 Bodø, Norway.

\section{Author details}

'Department of Occupational- and Environmental Medicine, University Hospital North Norway, Tromsø, Norway. ${ }^{2}$ Medical Pharmacology and Toxicology, Department of Medical Biology, Faculty of Health Sciences, University of Tromsø, Tromsø, Norway. ${ }^{3}$ Department of Pharmacy, Faculty of Health Sciences, University of Tromsø, Tromsø, Norway.

Received: 21 February 2013 Accepted: 3 July 2013

Published: 20 July 2013

\section{References}

1. Nystedt S, Emilsson K, Larsson AK, Strombeck B, Sundelin J: Molecular cloning and functional expression of the gene encoding the human proteinase-activated receptor 2. Eur J Biochem 1995, 232:84-89.

2. Böhm SK, Kong W, Brömme D, Smeekens SP, Anderson DC, Connolly A, Kahn M, Nelken NA, Coughlin SP, Payan DG, Bunnett NW: Molecular cloning, expression and potential functions of the human proteinase-activated receptor-2. Biochem J 1996, 314:1009-1016.

3. Ossovskaya VS, Bunnett NW: Protease-activated receptors: Contribution to physiology and disease. Physiol Rev 2004, 84:579-621.

4. Cocks TM, Fong B, Chow JM, Anderson GP, Frauman AG, Goldie RG, Henry PJ, Carr MJ, Hamilton JR, Moffatt JD: A protective role for protease-activated receptors in the airways. Nature 1999, 398:156-160.

5. Ramachandran R, Hollenberg MD: Proteinases and signalling: pathophysiological and therapeutic implications via PARs and more. Br J Pharmacol 2008, 153(Suppl 1):S263-S282.

6. Larsen AK, Seternes OM, Larsen M, Aasmoe L, Bang B: Salmon trypsin stimulates the expression of interleukin- 8 via protease-activated receptor-2. Toxicol Appl Pharmacol 2008, 230:276-282.

7. Orford RR, Wilson JT: Epidemiologic and immunologic studies in processors of the king Crab. Am J Ind Med 1985, 7:155-169.

8. Cartier A, Malo JL, Ghezzo H, McCants M, Lehrer SB: IgE sensitization in snow crab-processing workers. J Allergy Clin Immunol 1986, 78:344-348,

9. Jeebhay MF, Robins TG, Lehrer SB, Lopata AL: Occupational seafood allergy: a review. Occup Environ Med 2001, 58:553-562.

10. Jeebhay MF, Robins TG, Miller ME, Bateman E, Smuts M, Baatjies R, Lopata AL: Occupational allergy and asthma among salt water fish processing workers. Am J Ind Med 2008, 51:899-910.

11. Ortega HG, Daroowalla F, Petsonk EL, Lewis D, Berardinelli S Jr, Jones W, Kreiss K, Weissman DN: Respiratory symptoms among crab processing workers in Alaska: Epidemiological and environmental assessment. Am J Ind Med 2001, 39:598-607.

12. Bang B, Aasmoe L, Aamodt BH, Aardal L, Andorsen GS, Bolle R, Bøe R, Van Do T, Evans R, Florvåg E, Gram IT, Huser PO, Kramvik E, Løchen ML, Pedersen B, Rasmussen T: Exposure and airway effects of seafood industry workers in Northern Norway. J Occup Environ Med 2005, 47:482-492.

13. Howse D, Gautrin D, Neis B, Cartier A, Horth-Susin L, Jong M, Swanson MC Gender and snow crab occupational asthma in Newfoundland and Labrador, Canada. Environ Res 2006, 101:163-174.

14. Gautrin D, Cartier A, Howse D, Horth-Susin L, Jong M, Swanson M, Lehrer S, Fox G, Neis B: Occupational asthma and allergy in snow crab processing in Newfoundland and Labrador. Occup Environ Med 2010, 67:17-23.

15. Shiryaeva O, Aasmoe L, Straume B, Bang BE: Respiratory impairment in Norwegian salmon industry workers: a cross-sectional study. J Occup Environ Med 2010, 52:1167-1172.

16. Larsen AK, Seternes OM, Larsen M, Kishimura H, Rudenskaya GN, Bang B: Purified sardine and king crab trypsin display individual differences in PAR-2-, NF-kB-, and IL-8 signaling. Toxicol Environ Chem 2011, 93:1991-2011

17. Kangas E, Tidor B: Optimizing electrostatic affinity in ligand-receptor binding: Theory, computation, and ligand properties. J Chem Phys 1998, 109:7522-7545.

18. Green DF, Tidor B: Evaluation of electrostatic interactions. In Curr Protoc Bioinformatics. 2003 Aug; Chapter 8:Unit 8.3. doi:10.1002/0471250953. bi0803s02.

19. Rang HP, Dale MM, Ritter JM: How drugs act: general principles and molecular aspects. In Pharmacology. 4th edition. Edited by Hunter L. Edinburgh: Churchill Livingstone, Harcourt Brace and Company Ltd; 1999:2-45

20. Rudenskaya GN, Isaev VA, Shmoylov AM, Karabasova MA, Shvets SV, Miroshnikov Al, Brusov AB: Preparation of proteolytic enzymes from Kamchatka crab Paralithodes camchatica hepatopancreas and their application. Appl Biochem and Biotech 2000, 88:175-183.

21. Kislitsyn YA, Rebrikov DV, Dunaevskii YA, Rudenskaya GN: Isolation and primary structure of trypsin from the King crab Paralithodes camchaticus. Russian J of Bioorg Chem 2003, 29:242-248.

22. Kishimura $\mathrm{H}$, Hayashi $\mathrm{K}$, Miyashita $\mathrm{Y}$, Nonami $\mathrm{Y}$ : Characteristics of trypsins from the vicera of true sardine (Sardinops melanostictus) and the pyloric ceca of arabesque greenling (Pleuroprammus azonus). Food Chem 2006, 97:65-70.

23. Outzen $\mathrm{H}$, Berglund $\mathrm{Gl}$, Smalås $\mathrm{AO}$, Willassen NP: Temperature and $\mathrm{pH}$ sensitivity of trypsins from Atlantic Salmon (Salmo salar) in comparison with bovine and porcine trypsin. Comp Biochem Physiol B Biochem Mol Biol 1996, 115:33-45. 
24. Erlanger BF, Kokowsky N, Cohen W: The preparation and properties of two new chromogenic substrates of trypsin. Arch Biochem Biophys 1961, 95:271-278.

25. Abagyan R, Totrov M: Biased probability Monte Carlo conformational searches and electrostatic calculations for peptides and proteins. J Mol Biol 1994, 235:983-1002.

26. Bah A, Chen Z, Bush-Pelc LA, Mathews FS, Di Cera E: Crystal structures of murine thrombin in complex with the extracellular fragments of murine protease-activated receptors PAR3 and PAR4. Proc Natl Acad Sci USA 2007, 104:11603-11608.

27. Smalås AO, Hordvik A, Hansen LK, Hough E, Jynge K: Crystallization and preliminary X-ray crystallographic studies of benzamidine-inhibited trypsin from the North Atlantic salmon (Salmo Salar). J Mol Biol 1990, 214:355-358.

28. Ramachandran R, Mihara K, Mathur M, Rochdi MD, Bouvier M, DeFea K, Hollenberg MD: Agonist-biased signalling via proteinase activated receptor-2: differential activation of calcium and MAPkinase pathways. Mol Pharmacol 2009, 76:791-801.

29. Wei H, Ahn S, Shenoy SK, Karnik SS, Hunyady L, Luttrell LM, Lefkowitz RJ: Independent beta-arrestin 2 and $\mathrm{G}$ protein-mediated pathways for angiotensin II activation of extracellular signal-regulated kinases 1 and 2. Proc Natl Acad Sci USA 2003, 100:10782-10787.

30. Galandrin S, Oligny-Longpré G, Bouvier M: The evasive nature of drug efficacy: implications for drug discovery. Trends Pharmacol Sci 2007, 28:423-430.

31. Kenakin T: Collateral efficacy in drug discovery: taking advantage of the good (allosteric) nature of 7TM receptors. Trends Pharmacol Sci 2007 , 28:407-415.

32. Urban JD, Clarke WP, von Zastrow M, Nichols DE, Kobilka B, Weinstein $H$, Javitch JA, Roth BL, Christopoulos A, Sexton PM, Miller KJ, Spedding M, Mailman RB: Functional selectivity and classical concepts of quantitative pharmacology. J Pharmacol Exp Ther 2007, 320:1-13.

33. Saxena AK, Alam I, Dixit A, Saxena M: Internet resources in GPCR modelling. SAR QSAR Environ Res 2008, 19:1 1-25.

34. Blackhart BD, Ruslim-Litrus L, Lu CC, Alves VL, Teng W, Scarborough RM, Reynolds EE, Oksenberg D: Extracellular mutations of protease-activated receptor-1 result in differential activation by thrombin and thrombin receptor agonist peptide. Mol Pharmacol 2000, 58:1178-1187.

35. Gerszten RE, Chen J, Ishii M, Ishii K, Wang L, Nanevicz T, Turck CW, Vu TK Coughlin SR: Specificity of the thrombin receptor for agonist peptide is defined by its extracellular surface. Nature 1994, 368:648-651.

36. Nanevicz T, Ishii M, Wang L, Chen M, Chen J, Turck CW, Cohen FE, Coughlin SR: Mechanisms of thrombin receptor agonist specificity. Chimeric receptors and complementary mutations identify an agonist recognition site. J Biol Chem 1995, 270:21619-21625.

37. Al-Ani B, Wijesuriya SJ, Hollenberg MD: Proteinase-activated receptor 2 : differential activation of the receptor by tethered ligand and soluble peptide analogs. J Pharmacol Exp Ther 2002, 302:1046-1054.

38. Zhang $\mathrm{Q}$, Petersen $\mathrm{HH}$, Ostergaard $\mathrm{H}$, Ruf W, Olson AJ: Molecular dynamics simulations and functional characterization of the interactions of the PAR2 ectodomain with factor Vlla. Proteins 2009, 77:559-569.

\section{Submit your next manuscript to BioMed Central and take full advantage of:}

- Convenient online submission

- Thorough peer review

- No space constraints or color figure charges

- Immediate publication on acceptance

- Inclusion in PubMed, CAS, Scopus and Google Scholar

- Research which is freely available for redistribution 